Informatio: Journal of Library and Information Science Vol. 1(2), 181-194, Juli 2021

ISSN 2775-0043 (Online)

\title{
Pengetahuan lokal dan strategi lokal Sunda dalam hadapi bencana
}

\author{
Samson CMS ${ }^{*}$, Wina Erwina ${ }^{b}$, Elnovani Lusiana ${ }^{c}$ \\ abcFakultas Ilmu Komunikasi Universitas Padjajaran Bandung
}

\begin{abstract}
Abstrak
Keterpaduan para pemuka masyarakat dengan pemerintahan dalam segala aspek kehidupan penting sekali keberadaannya, tidak terkecuali dalam menghadapi berbagai bencana. Belum juga pandemic covid 19 pergi, bencana longsor, banjir, tsunami, gempa bumi, gunung Meletus, dll., yang tidak kunjung reda. Fakta bahwa selalu tidak tepatnya pendekatan yang digunakan, sering kali menyebabkan tidak maksimalnya penanganan. kurangnya masyarakat responsive turut serta dalam pencegahan semakin memperpanjang perjalanan penanganannya. Penelitian ini dilakukan dengan tujuan untuk mengetahui bagaimana tradisi lokal dalam hal ini orang Sunda di Tatar Karang dalam mengharmoniskan masyarakat dengan pemerintah dalam menghadapi bencana. Metode yang digunakan fenomenologi. Hasil penelitian menunjukkan: 1) pengetahuan lokal tentang mitigasi bencana; 2) ketaatan berdasarkan Adat, Agama dan Negara. Simpulan: pengetahuan lokal tersimpan salah satunya dalam wujud tradisi tertentu, di sebuah kelompok masyarakat. Hanya masyarakatnya yang mengetahui dimana pengetahuan-pengetahuan tersebut disimpan. Orang luar yang berkepentingan, sebaiknya arif mengetahui cara masing-masing adat memperlakukan pengetahuan lokalnya.
\end{abstract}

Kata kunci: Pengetahuan lokal; Mitigasi bencana; Tatar karang

Korespondensi: Samson CMS., S.Sos., M.I.Kom. Program Studi Perpustakaan dan Sains Informasi Fakultas Ilmu Komunikasi Universitas Padjadjaran Jalan Raya Bandung-Sumedang KM 21 Jatinangor, Indonesia

Email: samson.cms@unpad.ac.id

http://jurnal.unpad.ac.id/informatio

DOI: https://doi.org/10.24198/inf.v1i2.34268

Received: Juni 2021; Accepted: Juli 2021; Published: Juli 2021

(C) Informatio 2021. This is an open access article under the CC BY-SA license 


\title{
Indigenous Knowledge and Sunda local strategy to face a disaster
}

\begin{abstract}
The integration of community leaders with the government in all aspects of life is very important, including in the edges of various disasters. Not to mention the covid 19 pandemic, landslides, floods, tsunamis, earthquakes, erupting mountains, etc., which have not subsided. The fact that the wrong approach is always used, often the handling results in not maximum. The lack of responsive communities participating in prevention further prolongs the course of treatment. This study was conducted with the aim of finding out how local traditions, in this case the Sundanese in Tatar Karang, harmonize the community with the government in dealing with disasters. The method used is phenomenology. The results showed: 1) local knowledge about disaster mitigation; 2) obedience based on Custom, Religion and State. Conclusion: one of the local knowledge is stored in the form of certain traditions, in a community group. Only the people know where the knowledge is stored. Interested outsiders should be wise to know how each adat treats its local knowledge.
\end{abstract}

Keywords: Local knowledge; Disaster mitigation; Tatar karang

\section{PENDAHULUAN}

Nusantara atau Indonesia kini, sudah sejak lampau diakui dunia sebagai negara yang memiliki keragaman suku bangsa, budaya, kekayaan alam yang melimpah, peninggalan peradaban yang tinggi dan lain sebagainya. Terbukti sampai hari ini, Indonesia masih dan akan terus menjadi salah satu target dari negaranya untuk mengetahui bahkan menguasai berbagai aset yang ada di ibu pertiwi termasuk asset pengetahuan-pengetahuan lokal yang masih ada dalam alam pikiran manusia Indonesia (tacit knowledge) yang tersebar dari Sabang sampai Merauke. Jika merujuk pada UndangUndang No. 5 tahun 2017 tentang Pemajuan Kebudayaan pada pasal 5 bahwa Objek Pemajuan Kebudayaan meliputi: a. tradisi lisan; b. manuskrip; c. adat istiadat; d. ritus; e. pengetahuan tradisional; f. teknologi tradisional; g. seni; h. bahasa; 1. permainan rakyat; dan J. olahraga tradisional (kebudayaan.kemdikbud.go.id, 2017). Andai saja pengetahuanpengetahuan ini dapat kita dokumentasi dengan baik, diorganisasi dengan baik dan didayagunakan, maka kita akan memiliki banyak sumber pengetahuan dan referensi yang khas.

Hari - hari ini, percisnya awal tahun 2021 telah terjadi berbagai bencana di negara kita, dari mulai, banjir, longsor, pesawat jatuh, krisis moral diantaranya korupsi terkait anggaran penanganan covid - 19, dan lain sebagainya. Padahal pandemic corona (covid 19) yang datang sejak maret 2020 lalu, belum juga kunjung reda. Dalam tulisan ini, penulis bermaksud menyajikan bagaimana nenek moyang bisa tangguh dalam menghadapi berbagai bencana. Hal tersebut di telusur melalui sumber-sumber pengetahuan lokal yang diwariskan oleh mereka. Dalam kesempatan ini studi pada masyarakat Sunda di Tatar 
Karang Desa Sindangkerta kecamatan Cipatujah Kabupaten Tasikmalaya. Indonesia adalah satu-satunya negara kepulauan terbesar di dunia, dikelilingi lautan, negara yang paling banyak gunung berapinya, dihapit oleh dua benua, dilewati garis khatulistiwa, terbanyak suku bangsa yang didalamnya beragama adat-istiadat, tradisi dan kebudayaan, dan lain sebagainya. Tentu, dapat dipastikan kalau negara ini, akan memiliki sumber-sumber pengetahuan lokal yang banyak dan beragam. Termasuk pula, sumber pengetahuan terkait mitigasi bencana disinyalir banyak terdapat di Indonesia. Hal ini disampaikan oleh banyak pihak, termasuk para ahli kebencanaan baik di luar negeri maupun di dalam negeri. Mengapa demikian? Karena yang utama indikatornya adalah negara kepulauan terluas dengan banyaknya gunung berapi aktif dari sejak masa lalu hingga hari ini. Dan tidak mungkin manusia Indonesia bisa sampai dengan hari ini, ketika nenek moyang kita, tidak memiliki pengetahuan terkait mitigasi bencana.

Negara ini begitu luas, sehingga dalam upaya menelisik pengetahuan lokal tentang bagaimana manusia Indonesia tangguh dalam menghadapi bencana. Dan seperti apa strateginya dalam mencapai memasyarakatkan kesiapsiagaan yang "tanggap-tangkastangguh" dalam menghadapi bencana tersebut. Maka siapa pun memerlukan waktu, tenaga dan titik fokus. Untuk itu, dalam riset ini, kami hanya mengambil contoh menggali pengetahuan lokal Manusia Sunda, dan karena Sunda pun beragam, maka dalam kesempatan ini melakukan penelitian di masyarakat Tatar Karang kecamatan Cipatujah kabupaten Tasikmalaya provinsi Jawa Barat. Dengan pertimbangan, setelah melakukan riset pada tahun 2018, kami menemukan beberapa fakta dan data terkait kawasan ini, memiliki potensi bencana yang besar. Warga lokal memiliki Uga (prediksi kedepan berdasarkan kajian adat) yang disebut dengan: "Sagara Saba Darat" maksudnya, bahwa pada masa tertentu akan terjadi tsunami yang maha dahsyat (Awangga, 2018). Hal ini, dibenarkan hari oleh hasil-hasil penelitian modern bahwa, di pantai selatan Jawa Barat akan terjadi Mega Trust 8,4 skala richter.

Kedepan setelah ditemukan tentang bagaimana pengetahuan lokal dalam mitigasi bencana pada masyarakat Sunda, hal ini akan menjadi contoh dan bahan riset lanjutan di daerah adat lainnya. Sehingga dengan pendekatan lokal ini, harapannya akan mendapatkan sebuah solusi yang solutif dan tidak bersitegang dengan kosmologinya. Orang bijak bilang "dimana bumi dipijak, disana langit dijunjung" sepadan dengan itu dalam bahasa Sunda dikenal dengan peribahasa: "ciri sabumi, cara sadésa", nama di Tatar Karang ada tambahan ungkapan "bumi boga ciri désa bog acara", maksud bahwa setiap desa (kelompok masyarakat) sudah diberi Tuhan, memiliki cara/sistem dalam mengurus 
kehidupannya masing-masing yang solutif dan harmoni dengan semesta alam (Awangga, 2018).

\section{METODE PENELITIAN}

Penelitian ini menggunakan pendekatan kualitatif fenomenologi. Pendekatan fenomenologi berhubungan dengan pemahaman tentang bagaimana realita keseharian, dunia intersubjektif (dunia kehidupan). "Fenomenologi memiliki tujuan untuk menginterpretasikan tindakan sosial kita ataupun orang lain sebagai sesuatu yang bermakna (dimaknai) serta rekonstruksi turunan makna (makna yang digunakan saat berbeda) dari tindakan yang bermakna pada komunikasi intersubjektif individu dalam dunia kehidupan sosial" (Sudarmanti, 2006:). Menurut Alfred Schutz "dalam fenomenologi dikenal istilah "self-elucidation" atau "penjelasan atau uraian diri" yang dalam pelaksanaannya peneliti lebih banyak menggali: apa yang mereka katakana, apa yang mereka pikirkan, apa yang mereka tafsirkan tentang dunia mereka" (Nalan, n.d.).

Pengumpulan data dilakukan dengan observasi dan wawancara. Pengamatan dalam kegiatan observasi dilakukan pada: (a) tempat-tempat yang dijadikan sebagai unsur mitigasi bencana; (b) larangan adat yang dianggap sudah dialih fungsi; dan (c) lingkungan dan tempat bekas/artefak bencana. Kegiatan wawancara dilakukan kepada narasumber kunci yaitu tokoh adat, ketua adat dan ulama yang lekat dengan tata adat. Informan lainnya adalah masyarakat yang pernah terpapar bencana dan perangkat desa.

\section{HASIL DAN PEMBAHASAN}

\section{a. Pengetahuan Lokal Tentang Mitigasi Bencana}

Secara geografis wilayah adat Tatar Karang memiliki potensi terkait dengan sumber bencana seperti: gempa bumi, gunung meletus, angin barat, banjir kiriman, kekeringan, bencana yang datangnya dari lautan, utamanya dari samudra hindia seperti tsunami, dan lain-lain. Berikut data potensi bencana di wilayah adat Tatar Karang: 
Tabel 1. Potensi Bencana Sindangkerta

\begin{tabular}{ccc}
\hline No. & Jenis Bencana & $\begin{array}{c}\text { Potensi berdasarkan } \\
\text { kejadian }\end{array}$ \\
\hline 1 & Tsunami & $2004-2006$ \\
2 & Gempa Bumi & Sering sekali \\
3 & Banjir Bandang & Langganan \\
4 & Banjir Rob & Langganan \\
5 & Angin Barat & Langganan \\
6 & Kekeringan & Jarang \\
7 & Longsor & Jarang \\
\hline
\end{tabular}

Sumber: Hasil Pengamatan Peneliti (2021)

Hal senada disampaikan terkait potensi bencana di wilayah ini yang disampaikan oleh tim ahli dari Ekspedisi DESTANA (Desa Tangguh Bencana) Regional Jawa Badan Nasional Penanggulangan Bencana yang dilaksanakan pada tanggal 12-17 Agustus 2019. Kemudian adanya sungai-sungai besar yang langsung menjorok ke lautan (muara-muara besar), menambah potensi terjadinya banjir bandang dari arah utara dan banjir rob dari arah Samudra Hindia (Hanifa, 2019). Yang menjadi pertanyaan tim Ekspedisi Destana, kenapa wilayah ini (desa Sindangkerta) kecamatan Cipatujah kabupaten Tasikmalaya pada Tsunami 2006 tidak terdampak secara "berarti". Berbeda dengan wilayah lain yang sama-sama satu hamparan, seperti desa Cipatujah, desa Ciandum yang berada di sebelah barat dari desa Sindangkerta. Padahal titik Tsunami 2006 saat itu dari arah timur (Pangandaran), logika sederhana, seharusnya wilayah desa Sidangkerta akan lebih terdampak dari pada kedua desa tadi yang lebih jauh dari titik Tsunami Pangandaran, lihat gambar 1 narasi ini juga yang menjadi motif penulis ingin menguak strategi apa yang menjadikan masyarakat Sindangkerta terhindar dari musibah tersebut. Bahkan Orang Sunda Tatar Karang sudah sejak lama memiliki pengetahuan berikut cara menghadapinya tentang yang kita kenal hari ini "Tsunami”, mereka menyebutnya dengan istilah Sagara Saba Darat. 


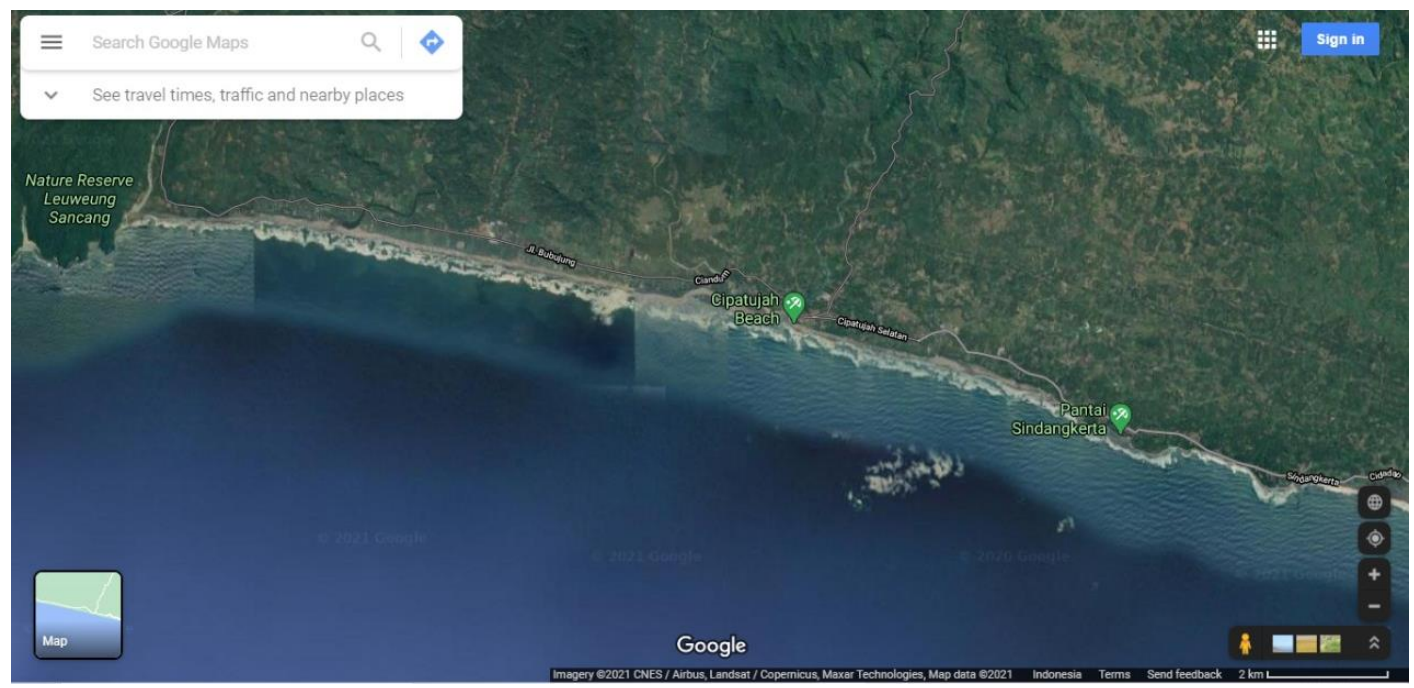

Gambar 1. Peta Kawasan Pantai Cipatujah

Sumber: Google Map (2021)

Masyarakat Tatar Karang memiliki perangkat sistem dalam upaya membangun kewaspadaan kepada seluruh warganya atas apa yang akan terjadi dimasa akan datang. Terkait dengan ancaman bencana, seperti yang tertera pada tabel 1 di atas, bahwa manusia Tatar Karang sudah dapat memprediksinya. Aki Awa Awangga menuturkan bahwa:

Iinditan kunaon kami nyaho nubakal datang? Lain datang ujug-ujug, tapi di dieu mah bog cara nya éta; raba taun. Maksudna nalika rék pindah taun, sok geus dikotéktak naon nu bakal kajadian boh alusna sumawona goréng. Paling henteu sataun kahareup kalan-kalan nepi ka meuntas lima nepi sapuluh taun kahareup. Lain rék nolak bala, lamu téa mah rék aya pibalaeun, tapi menta salamet atawa lamu apal kahareup pialuseun, kumaha sangkat bisa tumarima” (Awangga, 2018).

Artinya: yang menjadi latar belakang orang Tatar Karang mengetahui apa yang akan terjadi? Buka tanpa sebuah proses, tetapi di Tatar Karang memiliki cara yaitu; raba taun. Maksudnya ketika akan perpindahan tahun (Hijriyah dan Masehi), sudah ditelusuri informasi terkait apa yang akan terjadi baik kabar baik maupun kabar buruk. Paling tidak informasi setahun kedepan kadang-kadang hingga lima sampai sepuluh tahun kedepan. Bukan untuk menolak bencana, jikalau memang akan ada bencana, tetapi sekedar upaya memohon keselamatan atau jikalau kedepan kabarnya menggembirakan, bagaimana berupaya dapat mensyukurinya. 
Pernyataan Awangga tersebut merupakan rangkaian proses dari Raba taun (prediksi berdasarkan sumber pengetahuan lokal Tatar Karang). Raba taun adalah kunci dari segala tindakan kolektif masyarakat Tatar Karang, terkait perencanaan hidup mereka. Raba taun merupakan konsep dari tindakan kolektifnya, dan Narawang Kahareup adalah metodenya. Yang menarik pengetahuan ini terus diwariskan secara turun-temurun dan transfer knowledge ini disampaikan tidak terbatas pada keluarga yang memiliki pengetahuan tersebut atau seuweu-putu (garis keturunan) pemuka kampung, tetapi siap pun yang memiliki kemauan dan "kepekaan" terhadap pengetahuan tersebut. Walaupun tentu adat memiliki mekanisme (caranya sendiri) dalam menjaring siapa yang pantas menjadi gatekeeper dari pengetahuan tersebut. Tujuannya semata-mata supaya informasi tetap tersampaikan dengan minimum noise (selalu A1). Kesadaran untuk selalu mentransfer pengetahuan adat-nya ini, dengan beragam perangkat dan medium diseminasinya menambah panjang ketertiban manusia Tatar Karang dalam menjaga dan mewariskan pengetahuannya. Terkait pengetahuan lokal ini, Sibarani (2014) menjelaskan bahwa "Pengetahuan asli atau pengetahuan lokal merupakan segala bentuk pengetahuan dan perlakuan masyarakat lokal yang sepanjang sejarah telah dipraktikkan dalam berinteraksi dengan lingkungan alam" (Sibarani, 2014:122). Sementara Permana dkk. (2011) menjelaskan bahwa:

Kearifan lokal merupakan pandangan dan pengetahuan tradisional yang menjadi acuan dalam berperilaku dan telah dipraktekkan secara turun-temurun untuk memenuhi kebutuhan dan tantangan dalam kehidupan suatu masyarakat. Kearifan lokal berfungsi dan bermakna dalam masyarakat baik dalam pelestarian sumber daya alam dan manusia, pemertahanan adat dan budaya, serta bermanfaat untuk kehidupan (Permana, Raden Cecep Eka. Nasution, Isman Pratama. Gunawijaya, 2011:68).

Bagaimana adat Tatar Karang dalam mengorganisasi pengetahuannya terkait mitigasi bencana, tentu seperti yang dipaparkan Sibarani di atas. Sehingga dari masa ke masa menjadi belif mereka. Untuk konteks mewaspadai ancaman berbagai bencana dari sumber air misalnya, adat Tatar Karang sudah memiliki sistem yang mapan, seperti misalnya mereka memiliki tradisi Marak yang dilaksanakan satu hingga dua kali dalam setahun. "Marak, sesebutan ngala lauk babarengan di tempat umum, biasana di walungan atawa di muara " (CMS, Samson., 2018:20). "Artinya marak merupakan sebuah tradisi menangkap ikan bersama-sama di tempat umum, biasanya di sungai atau muara" (CMS., Samson, Kusandar, Lusiana, 2020:594). Awangga menjelaskan bahwa: 
Di kidul mah jadi liliwatan cai ti kalér, numatak sok remen ca’ah déngdéng, ana komo usum ngijih datang mah. Soalna di kidul mah loba walungan gedé anu jadi pangparatan cai ti kalér. Siga di kecamatan Cipatujah, ti wetanna: muara Cilangla, Cipatireman, ti kulona: aya muara Pasanggrahan, aya muara Muncang Kohok, muara Cipangremisan, muara Alur, muara Cikaéngan, jrrd. Numatak munasabah mun di dieu loba tarékah pikeun ngungkulan mamala tina éta pasualan, boh ti caina boh ti daratna." (Wawancara. Awangga. Oktober 2019). Artinya: di kidul menjadi jalur air yang datangnya dari utara, sehingga seringkali terjadi air kiriman, apalagi ketika datang musim penghujan. Karena di Kidul terdapat banyak sungai besar yang menjadi tembusan air dari utara. Seperti di kecamatan Cipatujah, dari sebelah timur: terdapat muara Cilangla, Cipatireman, dari sebelah barat: muara Pasanggrahan, muara Muncang Kohok, muara Cipangremisan, muara Alur, muara Cikaéngan dll. Maka wajar saja di sini banyak pendekatan untuk keluar dari sumber ancaman tersebut baik dari perairan maupun di daratan (CMS., Samson, Kusandar, Lusiana, 2020:605).

Sesungguhnya pengetahuan tentang bencana orang Tatar Karang, begitu banyak dan komprehensif sumber-sumber data dan informasinya. Fenomenanya masih ada, tradisi lisannya masih dipelihara, penjaga pengetahuan dan pendukungnya masih ada, artefaknya ada, dan masih banyak yang lainnya. Mereka mengenal bahwa bencana datang diakibatkan oleh sumber alam, makhluk lain yang hidup sama dengan manusia, ulah manusia dan konflik sosial. Hal ini selaras dengan Undang-Undang No. 24 tahun 2007 tentang Penanggulangan Bencana pasal 1 menjelaskan bahwa bencana dibedakan menjadi: 1) bencana alam; 2) bencana non alam; dan 3) bencana sosial (Pemerintah, 2007:2).

Pengetahuan terkait dengan mitigasi bencana, salah satunya terpetakan melalui medium komunikasinya diantaranya: 1) Hajat Lembur, yang menjadi sentral komunikasi dan informasi terkait kebencanaan di Tatar Karang; 2) Rarangkén Paré adalah upaya terkait pengetahuan kepastian dan ketahanan pangan; 3) Rarangkén Sawah, adalah upaya memperkenalkan sebagian alat-alat early warning system; 4) Tradisi Marak, upaya adat mengedukasi warga tentang ancaman bencana yang sumbernya dari air dan kepastian gizi ikan air tawar; 5) dan lain-lain. Belum lagi terkait dengan sistem keamanan berbasis tata ruang, misalnya dikenal dengan: tilu katangtuan laranga (dua sebelah selatan perkampungan (di pesisir): Balé Kambang-Punaga Nungku dan satu di sebelah utara perkampungan: Leuweung Sangkur, Harim Laut, Pangagonan, Leuweung Larangan, dan 
lain-lain. Pengetahuan ketangguhan manusia Tatar Karang: tahu jalur evakuasi jika terjadi bencana dari lautan, mengetahui apa yang harus disiapkan dan selalu siap siaga apapun bencananya, setiap individu tahu perannya dikala terjadi bencana dan lain-lain. Tentang permainan untuk anak-anak terkait mitigasi bencana ada dan diwariskan, seperti Ulin Papancuhan, yaitu permainan yang memperkenalkan tentang dinamika ombak dan ancamannya; Ulin Jajangkang yang memperkenalkan arah hembusan angin; Ulin Momoroan yang memperkenalkan tradisi berburu, dan lain-lain. Menarik memang, dari mana mereka memiliki sumber-sumber pengetahuan komprehensif itu? Untuk menjawabnya, diperlukan riset lanjutan.

Hal yang terpenting hari ini adalah bagaimana agar segenap putra bangsa, menjadi dirinya yang mengenal jati dirinya, melalui melek budaya 'literate', dalam hal ini melek terhadap seluruh pengetahuan nenek moyang yang diwariskannya. Literate terhadap sumber-sumber pengetahuan lokal yang sesuai dengan kebutuhan atas kompetensinya masing-masing. Hal ini selaras dengan semangat Gerakan Literasi Nasional (GLN). Sebagai bagian dari pengembangan Peraturan Menteri Pendidikan dan Kebudayaan nomor 23 tahun 2015 tentang Penumbuhan Budi Pekerti.

Kemampuan untuk memahami keberagaman dan tanggung jawab warga negara sebagai bagian dari suatu bangsa merupakan kecakapan yang patut dimiliki oleh setiap individu di abad ke- 21 ini. Oleh karena itu, literasi budaya dan kewargaan penting diberikan di tingkat keluarga, sekolah, dan masyarakat. Literasi budaya dan kewargaan tidak hanya menyelamatkan dan mengembangkan budaya nasional, tetapi juga membangun identitas bangsa Indonesia di tengah masyarakat global (Hadiansyah, 2017:2).

Siapa yang harus literate itu? Antara lain: keluarga, sekolah dan masyarakat. Maka tahapan dasar yang harus dilakukan adalah edukasi enam literasi dasar, terutama literasi yang kelima dan keenam yaitu literasi sains dan literasi budaya dan kewargaan.

\section{b. Ketaatan Berdasarkan Adat, Agama, dan Negara}

Berbicara aturan/peraturan hidup bermasyarakat di sebuah kelompok masyarakat, tentu sudah sebuah kelaziman dan kepatutan. Kemudian aturan-aturan tersebut bersandar pada tatanan apa, jika melihat hari ini fakta visual seolah manusia hari ini tidak berlandaskan pada keharmonian, baik dengan manusia lain, manusia dengan alam dan yang lainnya. Salah satu faktanya, kebijakan besar-besaran terkait alih fungsi lahan yang tidak seharusnya, eksploitasi sumber-sumber alam yang tidak mempertimbangkan 
'larangan adat' terkait mitigasi bencana, dan lain sebagainya. Padahal orang lokal di nusantara peraturan hidup tersebut selalu didasarkan pada norma adat, agama dan negara. "Sekitar tahun 301 SM, konsep bagaimana hidup harmoni dengan alam sudah disuarakan Zeno seorang pendiri mazhab filsafat Stoa/Stoisisme" (Sibarani, 2014). "Kemudian orang Sunda paling tidak sejak abad ke VII sudah tercatat dalam arsip kerajaan bahwa mereka memiliki tradisi bagaimana hidup bersahabat dengan alam, yaitu Sadrasa Kamanusaan (enam aspek moral manusia Sunda)" (CMS., Samson, Kusandar, Lusiana, 2020:603).

Bagaimana manusia Sunda melihat hal tersebut? Berdasar beberapa sumber dikatakan bahwa Sunda Lama sudah memiliki perangkat dalam upaya membangun manusia, baik sebagai Individu maupun Sosial. Hal tersebut dikuatkan oleh Suryalaga (2009), yang menjelaskan bahwa "Menuju manusia Unggul Sunda dibangun dalam penguatan kapasitas individu manusianya melalui "Sadrasa Kamanusaan" (enam asep moral kemanuisaan). Yaitu MMT (Moral Manusia terhadap Tuhan); MMP (Moral Manusia terhadap Pribadi; MMM (Moral Manusia terhadap Manusia lain); MMA (Moral Manusia terhadap Alam); MMW (Moral Manusia terhadap Waktu); MMLB (Moral Manusia terhadap kesejahteraan Lahir-Batin)" (Suryalaga, 2009:10,11,12). Hal tersebut, bersumber dari manuskrip Sanghyang Siksa Kanda'ng Karesian (SSKK) yang disalin ulang pada 1518 M. Berkaitan dengan strategi lokal dalam mitigasi bencana, Sunda sudah menguatkannya melalui: MMT, MMM, MMA dan MMW. Misalnya di MMT, individu Sunda dikendalikan dengan harus memiliki tingkat kualitas keimanan kepada Tuhannya apapun agama yang diyakininya. MMM, ditandai dengan individu Sunda harus berkemampuan silih-anjangan/anjang sono (bersosialisasi-hablumminannas, dsj). MMA, individu Sunda diharuskan memiliki kesadaran akan kesatuan geopolitik (wawasan kewilayahan, keutuhan wilayah termasuk keutuhan wilayah budaya). "Ditandai dengan kesadaran ekologi, baik terhadap alam sagir maupun alam kabir. Kesadaran akan alam ini bermula dari rumah tempat tinggal sampai wilayah lebih luas dan berakhir pada kesadaran di tataran global" (Suryalaga, 2009:10-11). MMW, individu Sunda seja dini sudah diperingatkan terkait kesadaran regenerasi (kaderisasi) bahwa pemimpin yang hebat adalah ia yang mampu menyiapkan penerus yang lebih berkualitas. Diperkuat dengan adanya "kesadaran waktu siklis/siklus (Bhs. Sunda: cakra manggilingan; gilir gumantina wanci; mulih ka jati mulang ka asal, congo nyurup dina puhu; rawayan jati, inalillahi wa inaillaihi roji'un) (Suryalaga, 2009:11).

Karakter utama yang membedakan manusia dengan makhluk hidup lainnya adalah akal. Manusia yang tidak mempergunakan akalnya akan terjadi dehumanisasi yang derajatnya sama dengan binatang. Manusia memiliki kapasitas berpikir yang sangat 
komplek dan canggih, memiliki kemampuan untuk membuat simbol itu menjadi alat berkomunikasi dalam bentuk bahasa, karena itu manusia mempunyai kemampuan mentransmisikan, mentransformasikan ide/gagasan/moral dan nilai dari satu generasi ke generasi berikutnya (Maryani, Enok. Yani, 2014:117)

Strategi Sunda Tatar Karang dalam upaya tidak terjadinya "dehumanisasi", terutama perilaku dalam berinterkasi dengan alam dan memperlakukan semesta alam, karena jika itu terjadi, bencana alam tidak bisa dielakan lagi. Maka dalam mempersiapkan diri dari ancaman sumber bencana, lokal disana menyebutnya "balai". Terdapat aturan hidup yang bersandar pada: 1) Larangan (adat); 2) Paharaman (Agama); dan 3) Harim (Negara). Sukmana (2020), mengatakan bahwa: "manusa boga kawajiban pikeun ngajaga tata hirupna jeung nu Kawasa. Manusa boga kawajiban ngajaga alam jeung ka papada makhluk nu aya di sagigireuna”. Artinya manusia memiliki kewajiban dalam menata hidupnya dengan sang Pencipta. Manusia memiliki kewajiban menjaga alam dan menjaga makhluk yang hidup berdampingan dengan dirinya.

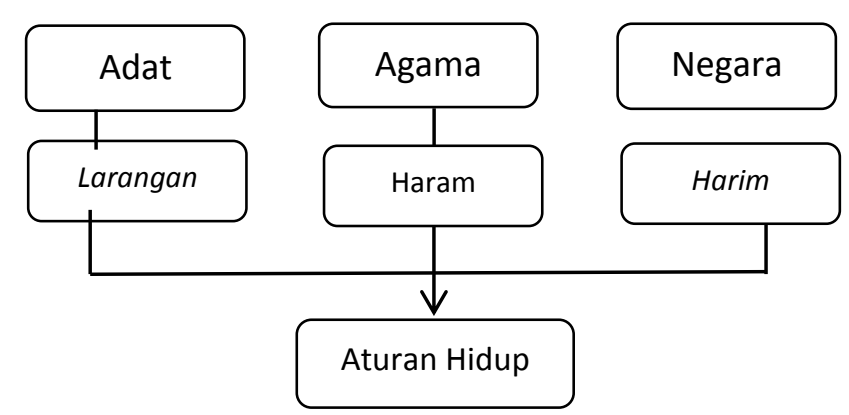

Gambar 2. Model Sistem Kendali Manusia Sunda Tatar Karang Sumber: Hasil Penelitian (2021)

Larangan: kearifan lokal terkait dengan pemilik dan yang tahu wilayah, lahan/tempat, benda, dsj., dan yang berwenang adat dengan aturan adat dan pemimpin adat atau tokoh adat; Haram adalah aturan pasti yang landasannya hukum agama bersumber dari Al Qur'an, Al Hadits dan Adat, dan yang berwenang pemuka agama dan tokoh agama; Harim kaitanya dengan batas-batas wilayah yang keputusannya dikeluarkan oleh negara/pemerintah, yang berwenang adalah negara/pengelola pemerintahan. Sukmana (2020) menjelaskan bahwa:

(1) ada wilayah "hak umum" bisa dimanfaatkan untuk kepentingan umum, seperti dalam adat disebut "Hakulah" contoh tanah pangangonan (tahah hak hewan), 
silahkan digarap/diolah tapi jangan dirusak/alih fungsi dan dimiliki. (2) ada wilayah kewajiban umum, tapi tidak bisa dimanfaatkan/digarap oleh umum karena akan berdampak ke umum, seperti mengganggu sumber mata air, bisa berakibat kekeringan di musim kemarau, membuka hutan larangan yang ada di perbukitan, bisa berakibat tanah longsor di musim penghujan (Sukmana, 2020).

Pengetahuan lokal sebagai pengetahuan asli dari wilayah setempat dimana tempat terjadinya bencana, akan lebih mengetahui dirinya untuk mencari jalan keluar baik mencegah sebelum terjadinya bencana sebagai tindakan preventif, juga tindakan ketika peristiwa bencana sedang dan sudah terjadi. Pengetahuan lokal adalah adat, tentu yang paling tahun dirinya adalah individunya sendiri (adat setempat). Analoginya, bagaimana dokter bisa mendiagnosa dengan tepat dan memberi obat kepada pasien dengan benar, ketika sang pasien tidak terbuka menyampaikan keluhan penyakitnya. Tindakan adat dalam menghadapi bencana, tidaklah reaktif, melainkan lebih kepada pencegahan (preventif). Sehingga, mereka (adat) tahun indikasi kapan wilayahnya rentang dengan bencana atau beresiko bencana.

Saat ini, sebaiknya semua pihak terutama pemangku kepentingan dalam hal ini pemerintah yang memiliki kekuasaan dan kewenangan dalam mengambil tindakan. Melalui satuan tugas yang membidangi kebencanaan dan unsur terkait yang menyertainya, dari pusat hingga daerah tingkat desa, harus literate terhadap bagaimana adat melakukan mitigasi bencana. Berarti GLN terkait dengan gerakan literasi budaya dan kewargaan harus dipastikan dilaksanakan oleh seluruha warga negara. Apalagi target sasarannya dalam Gerakan tersebut sudah jelas yaitu: keluarga, sekolah dan masyarakat. Menurut Sukmana (2020) "lamun para ulama geus pagiling-gisik jeung adat, bakal kuat, da bakal loba papanggihan. Ke dalilna bakal asup akal, da bakal ngadongeungkeun alam nyata" (Sukmana, 2020). Artinya Ketika para ulama sudah bergandengan tangan dengan adat, maka akan kuat, karena akan banyak pengetahuan dan pengalaman baru. Nanti dalil yang digunakan akan masuk akal, karena akan menganalogikan/menjelaskan apa yang mereka lihat di masyarakat.

\section{SIMPULAN}

Mitigasi bencana, bukan sekedar persiapan dan respons yang cepat dalam tanggap darurat, baik dalam: pra-bencana, sedang dan pasca-bencana. Bukan pula penelitianpenelitian kebencanaan yang semakin modern dan mutakhir atau ketersedian alat-alat canggih dalam penanganannya, melainkan bagaimana kita mampu empati atau peka 
terhadap apa yang sudah nenek moyang lakukan dalam menjaga kelangsungan hidup kita dari masa ke masa, dari berbagai ancaman bencana selama beratus bahkan beribu abad lamanya. Tidak mungkin mereka tidak melakukan upaya seperti apa yang dilakukan manusia hari ini, untuk mengupayakan generasinya terus berlanjut.

Mengenali jati diri adalah kuncinya, bagaimana kita bisa mengetahui dan respect terhadap apa yang sudah dikerjakan para nenek moyang. Perlu perspektif lain dalam kegiatan mitigasi bencana ini. 1) Pengetahuan lokal tentang mitigasi bencana yang diwariskan nenek moyang, sepatutnya kita dayagunakan di tanah air kita sendiri. Karena adat akan lebih tahun kampungnya, dibanding pihak lain yang datang selewat. 2) Ketaatan berlandaskan Adat, Agama dan Negara sepatutnya di wujudkan dengan Tindakan nyata. Bukankah pepatah bilang "dimana bumi dipijak disana langit dijunjung" dan orang Sunda bilang "bumi boga ciri désa boga cara". Cara adat dalam mitigasi bencana tidak perlu lagi diragukan. Bukankah keharmonisan manusia dengan semesta alam dicontohkan leluhur kita. Hidup harmonis dengan alam adalah ciri bangsa Indonesia.

\section{Kontribusi Pada Keilmuan}

Penelitian ini merupakan kajian dalam bidang pengetahuan lokal. Hasil penelitian ini dapat menjadi dasar untuk penelitian selanjutnya atau penelitian bidang sejenis mengenai pengetahuan lokal dan strategi lokal dalam menghadapi bencana. Penelitian ini juga dapat menjadi sumber inspirasi bagi penelitian bidang lain yang berhubungan dengan pengetahuan lokal dan strategi lokal dalam menghadapi bencana.

\section{Pernyataan Minat Kajian}

Peneliti bernama Samson CMS memiliki minat kajian dalam pengetahuan lokal, sedangkan peneliti bernama Wina Erwina memiliki minat kajian dalam bidang Literasi Informasi.

\section{Kontribusi Peneliti dan Pihak Lain}

Peneliti dengan nama Samson CMS melakukan wawancara dan observasi untuk mendapatkan data lapangan dan melakukan pengolahan data. Peneliti dengan nama Wina Erwina dan Elnovani Lusiana melakukan pengumpulan data dengan cara studi pustaka juga analisis data.

\section{DAFTAR PUSTAKA}

Awangga, A. (2018). Wawancara: Tentang Pengetahuan Narawang Karaeup di Tatar Karang. Saung Budaya Tatar Karang Sindangkerta.

CMS, Samson., S. (2018, July). Marak, Ngoyok jeung Ngawesi di Tatar Karang.

CMS., Samson, Kusandar, Lusiana, E. (2020). Tradisi Marak di Tatar Karang Antara Pemenuhan Gizi dan Mitigasi. Kajian Budaya Dan Humaniora, 2(3), 596-606. https://ranessmediarancage.wordpress.com/2021/01/22/jurnal-kajian-budaya-dan- 
humaniora-jkbh-volume-2-nomor-3-oktober-2020/

Hadiansyah, F. dkk. (2017). Buku Literasi Budaya dan Kewargaan. Jakarta : Kementerian Pendidikan dan Kebudayaan.

Hanifa, R. (2019). FGD terkait DESTANA Tsunami Regional Jawa: 12 -17 Agustus 2019 di Desa Sidangkerta. Badan Nasional Penanggulangan Bencana.

kebudayaan.kemdikbud.go.id. (2017). Undang-Undang nomor 5 tahun 2017 tentang Pemajuan Kebudayaan. https://kebudayaan.kemdikbud.go.id/ditkt/wpcontent/uploads/sites/6/2017/06/UU-Pemajuan-Kebudayaan-RI-nomor-5-tahun2017.pdf

Maryani, Enok. Yani, A. (2014). Kearifan Lokal Masyarakat Sunda dalam Memitigasi Bencana dan Aplikasinya sebagai Sumber Pembelajaran IPS Berbasis Nilai. Jurnal Penelitian Pendidikan, 14(2), 114-125. https://doi.org/10.17509/jpp.v14i2.3111

Nalan, A. s. (n.d.). Gaya Mendalang Murid-Murid Asep Sunandar Sunarya: Studi Fenomenologi Komunikasi Dalang Wayang Golek Purwa. Universitas Padjadjaran.

Pemerintah. (2007). Undang-Undang No. 24 tahun 2007 tentang Penanggulangan Bencana. Staff.Ugm.Ac.Id. https://luk.staff.ugm.ac.id/atur/sehat/UU-242007PenanggulanganBencana.pdf

Permana, Eka Cecep Raden. Nasution, Pratama Isman. Gunawijaya, J. (2011). Kearifan Lokal Tentang Mitigasi Bencana Pada Masyarakat Baduy. Makara Human Behavior Studies in Asia, 15(1), 67-76. https://doi.org/10.7454/mssh.v15i1.954

Sibarani, R. (2014). Kearifan kokal: Hakikat, peran dan metode tradisi lisan. Asosiasi Tradisi Lisan.

Sudarmanti, R. (2006). Memahami Fenomenologi Kesadaran Intersubjectif Alfred Schutz. Jurnal Univ Paramadina, 4(2), 144-157.

Sukmana. (2020). FGD: Tentang Mitigasi Bencana dalam Pendekatan Budaya dan Agama. Saung Budaya Tatar Karang Sindangkerta.

Suryalaga, H. (2009). Kasundaan Rawayan Jati (1st ed.). Bandung: Yayasan Nur Hidayah. 